\title{
The effectiveness of psychodrama techniques in improving the moral development of children with attention deficit hyperactivity disorder
}

\author{
Azadeh Haghshenas ${ }^{1}$, Hamidreza Rezaei ${ }^{2}$ \\ 1-Msc Psychology, Department of Psychology, Allameh Tabatabaei University, Tehran, Iran. \\ 2- Msc Psychology, Department of Educational Psychology, Shiraz University, Shiraz, Iran (Corresponding \\ Author). \\ E-mail: hamid_sk2003@yahoo.com
}

Received: 26/06/2020

Accepted: 12/09/2020

\begin{abstract}
Introduction: It is believed that the moral development of children with attention deficit hyperactivity disorder is defective. These children are deficient in moral judgment, making it difficult for them to interact with others.

Aim: The aim of this study is to evaluate the effectiveness of psychodrama techniques in improving the moral development of children with attention deficit hyperactivity disorder.

Method: The research method is a quasi-experimental study. The statistical population of this study consist of all children aged 7 to 12 years with attention deficit/ hyperactivity disorder who have been referred to Shiraz medical clinics in 2019 for treatment. Thirty children from the aforementioned population whose ADHD diagnosis were confirmed by a psychiatrist were selected as subjects and were randomly assigned to control and experimental groups. Then the subjects were asked to complete the Sinha \& Verma's moral judgment test and their scores were considered as pre-test scores. Then the experimental group received an intervention of "psychodrama techniques" for 1.5 hours per week for a duration of 8 weeks; while the control group did not receive any intervention. At the end of the intervention, both groups were asked to complete a post-test and were followed up 2 months after the intervention. The data are analyzed using one-way analysis of covariance in SPSS-22 software.
\end{abstract}

Results: The findings demonstrate that psychodrama techniques were effective on improving the moral development of children with attention deficit hyperactivity disorder $(\mathrm{P}<0.005)$.

Conclusion: According to the findings, psychodrama techniques can be used as an effective intervention to improve the moral development of children with attention deficit hyperactivity disorder.

Keywords: Attention deficit hyperactivity disorder, Moral development, Psychodrama, Child

How to cite this article : Haghshenas A, Rezaei $\mathrm{H}$. The effectiveness of psychodrama techniques in improving the moral development of children with attention deficit hyperactivity disorder. Shenakht Journal of Psychology and Psychiatry. 2020; 7 (4): 135-146 .URL: http://shenakht.muk.ac.ir/article-1-817-en.pdf

Copyright ( 92018 the Author (s). Published by Kurdistan University of Medical Sciences. This is an open access article distributed under the terms of the Creative Commons Attribution-Non Commercial License 4.0 (CCBY-NC), where it is permissible to download, share, remix, transform, and buildup the work provided it is properly cited. The work cannot be used commercially without permission from the journal. 


\title{
بررسى اثربخشى روش در مانى روان ذمايشكرى بر بهبود تحول اخلاقى كودكان مبتلا به اختلال بيش فعالى / نقص توجه
}

\author{
آزاده حقشناس'، حميدرضا رضايى' \\ ا. كارشناس ارشد روانشناسى، گروه روانشناسى، دانشخاه علامه طباطبايى، تهران، ايران.

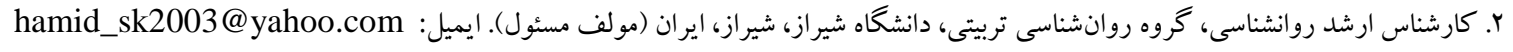

مقدمه: اعتقاد بر اين است كه قضاوت اخلاقى كود كان مبتلا به اختلال بيش فعالى / نقص توجه داراى نقص است، اين كود كان در ظرفيت قضاوت اخلاقى داراى كمبود هستند و اين نقص، تعامل را با ديخران دشوار مىسازد. هدف: يُزوهش حاضر با هدف بررسى اثربخشى روش درمانى روان نمايشخرى بر تحول اخلاقى كود كان داراى اختلال بيش فعالى/ نقص توجه انجام شد.

روش: يثوهش حاضر از نوع مطالعات نيمه آزمايشى بود. جامعه آمارى آن كودكان V تا Y I سال مبتلا به اختلال بيش فعالى / نقص

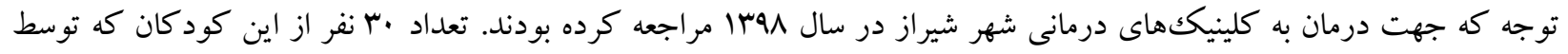

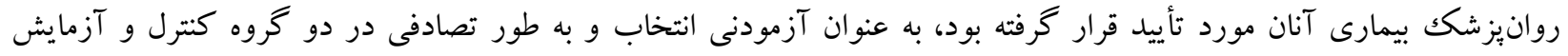

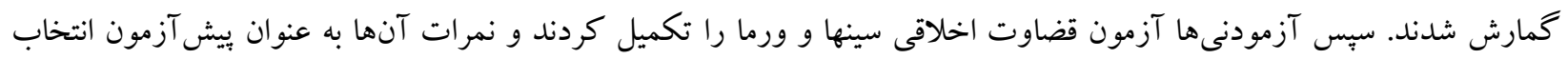

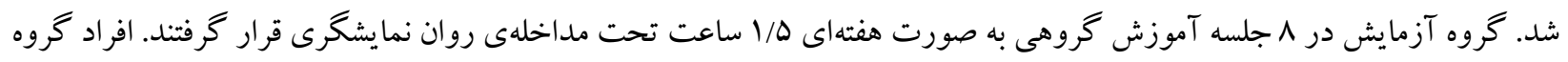

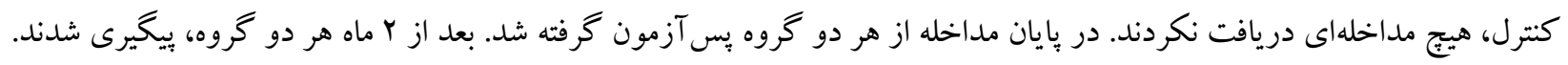

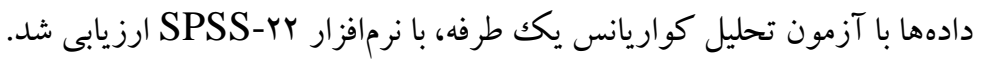
يافتهها: يافتها نشان داد كه روش درمانى روان نمايشگرى بر بهبود تحول اخلاقى در كود كان مبتلا به اختلال بيش فعالى / نقص توجه

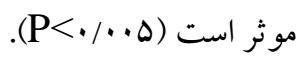
نتيجه كيرى: با توجه به يافتها از درمان روان نمايشخرى مىتوان به عنوان مداخلهاى موثر بر بهبود تحول اخلاقى كودكان مبتلا به

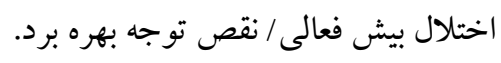
كليدوازهها: اختلال بيش فعالى/ نقص توجه، تحول اخلاقى، روان نمايشگرى، كودك 


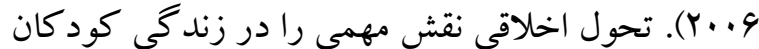
بازى مى كند و زيربنايى براى تعاملات است كه به كود كان براى تطابق با استانداردها در محيطشان كمك

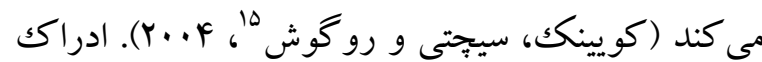
اخلاقى و استدلال اشاره به انخيزه هنهان رفتار كود كان يان واكنش در باسخ به يكك موقعيت خاص در محيط

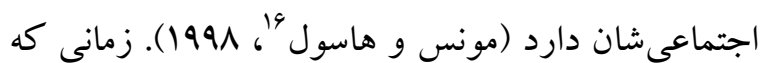
كودكك بتواند قضاوت كند كه در لحظه و در موقعيت و شرايط جֶه جيزى عادلانه و مناسب است، ادراكك اخلاقى و استنتاج تحول مى يابد. همانند ساير زمينهاى تحول اين روند يك بيوستكى را در طول بيوستار نشان مىدهد و و ماند تفكر به آرامى در گير و دار تعارض ميان نيازها و استانداردهاى اجتماعى تحول مى يابد (هافمن "I IVV9). برخى زمينهها نظير دلبستخى، داشتن تعاملات مثبت، آموزش به كود كان كمك مى كند تا قو انين اخلاقى سالم را توسعه دهند. بازسازى اطلاعات غيرمعمول كه توسط تعامل با محيط فيزيكى و اجتماعى و با مفاهيم موجود به دست مى آيد، درككهاى جديد و روشهاى جديد تفكر

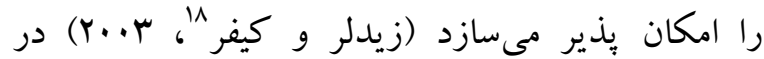

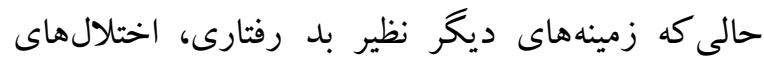
روانى از جمله شخصيت ضد اجتماعى (كريس و و إن

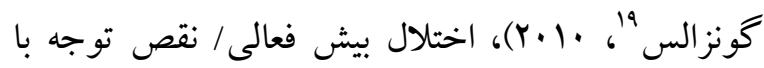
نقص در قضاوت اخلاقى و در نهايت با تشكيل اين قوانين در تقابل هستند.

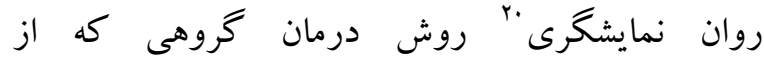
تصويرسازى ذهنى، تخيل، اعمال بدنى و بويايىهاى

15 - Koenig, Cicchetti \& Rogosch

16 - Mones \& Haswell

17. Hoffman

${ }^{18}$ - Zeidler \& Keefer

${ }^{19}$ - Kreps \& Gonzalez

20. Psychodrama مقلdمه

اختلال بيش فعالى/ نقص توجه' يك اختلال شايع روانى - عصبى - تحولى است (فرايونهُ و همكاران،

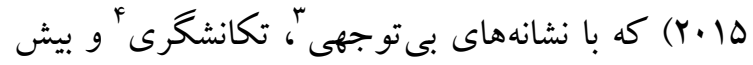
فعالى ه مشخص مىشود (انجمن روانيزشكى آمريكا؟ rا.Yr) و شيوعى در حدود ه درصد در كود كان دارد

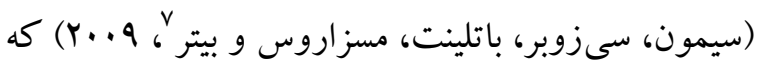

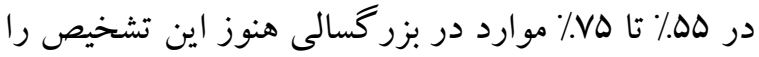

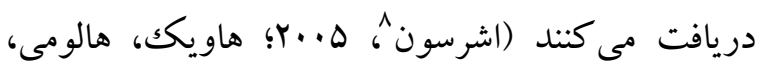

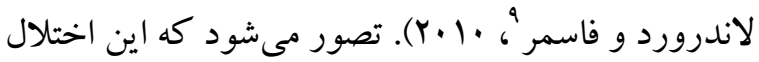
در نتيجه تعامل بيجيده بين زنتيك، محيط و عوامل روانى

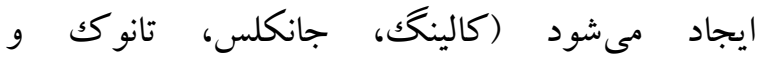

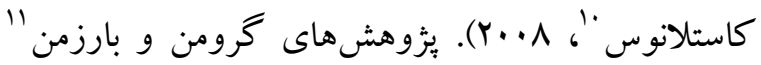

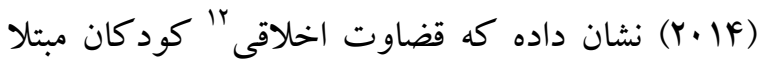
به اختلال بيش فعالى / نقص توجه داراى نقص است، اين كود كان در ظرفيت قضاوت اخلاقى داراى كمبود هستند و اين نقص تعامل را با ديخران دشوار مىسازد. اخلاق توانايى ما براى يادگيرى درست و غلط و فهم اين كه جطورى انتخابهاى درست داشته باشيم است. كلبر گك شش مرحله تحول اخلاقى بّ" را مطرح كرده است طبق نظر او تحول اخلاقى جهان شمول و براى همه افراد يكسان است و در ارتباط با أعنصر اساسى است: همدلى، صداقت، خود كنترلى و قضاوت (برودريكك و بلويت أ،

\footnotetext{
1- Attention deficit hyperactivity disorder (ADHD)

2 - Faraone

3 - Inattention

4- Impulsivity

5 - Hyperactivity

6- American Psychiatric Association

7- Simoon, Zoober, Batlint, Meszaros \& Bitter

8 - Asheson

9 - Havik, Halomy, Lundervorld \& Fasmer

${ }^{10}$ - Kieling, Goncalves, Tannock \& Castellanos

11 - Groman \& Barzman

12 - Moral judgment

13 - Moral development

14- Broderick \& Blewitt
} 
بنابراين با توجه به اين كه نقص در قضاوت اخلاقى در كود كان مبتلا به اختلال بيش فعالى/ نقص توجه مشاهده مى گردد و با توجه به اين كه در زمينهى اثربخشى روش درمانى روان نمايشگرى بر بهبود تحول اخلاقى كود كان مبتلا به اختلال بيش فعالى/ نقص توجه، يثوهشهاى اندكى به ويزه در داخل، صورت گُفته است، از اين رو عوامل بازدارنده يا مداخله كر در بهبود تحول اخلاقى اين

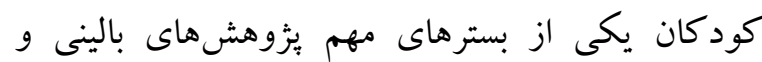
رشدى به شمار مىرود؛ لذا در اين بُزوهش، روش ئر درمانى روان نمايشگرى به عنوان عامل مداخله بهبود تحول اخلاقى كود كان مبتلا به اختلال بيش فعالى/ نقص توجه، مد نظر قرار گرفته است؛ بنابراين بيزوهش حاضر بر آن است تا اثربخشى روش درمانى روان نمايشگرى بر بهبود تحول اخلاقى كودكان مبتلا به اختلال بيش فعالى / نقص توجه را مورد بررسى قرار دهد.

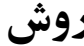

يزّوهش حاضر يكك مطالعه نيمه آزمايشى است كه با طرح بيش آزمون- يس آزمون به همراه گرروه كنترل انجام شد. جامعهى بثزوهش شامل تمامى كود كان V تا I ال سال مراجعه كننده به كلينيككهاى درمانى شهر شيراز در سال

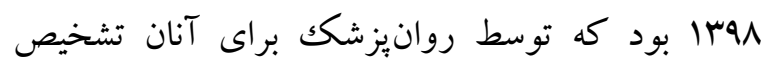
اختلال بيش فعالى/ نقص توجه داده شده بود. جهت

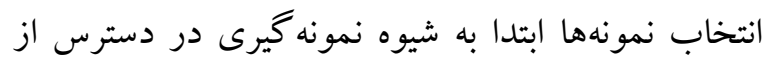
بين كود كان جامعه فوق، تعداد ·ـ كودكك انتخاب و به طور تصادفى در دو گروه كنترل (ها نفر) و كروه آزمايش (ها نفر) قرار داده شدند. سبس آزمودنىها آزمون قضاوت اخلاقى را تكميل كردند و نمراتشان به عنوان نمره بيش آزمون در نظر گرفته شد. گروه مداخله بعد از اجراى بيش آزمون، طى ·1 جلسه به مدت دو
كروه استفاده مى كند. فرض بر اين دارد كه اغلب مشكلات و آشفتگىهاى هيجانى و از جمله ناتوانى در ابراز گرى هيجانى و بازدارى، بيشتر ناشى از فقدان خودانگيختكى، خزانه نقش توسعه نيافته و متعاقب آن نقصان مهارتهاى رفتارى مرتبط با نقشهاست (مورنو،

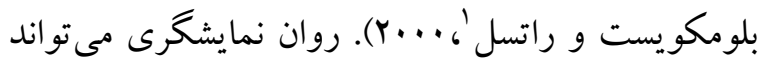
بر هر يكك يا همه قلمروهاى رفتارى، هيجانى، افكار و روابط بين فردى با توجه به آنجه كه درمان جويان نياز به

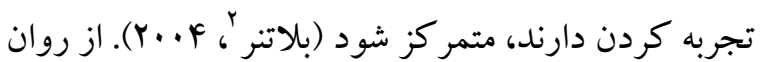

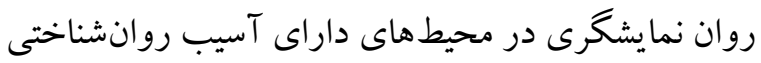

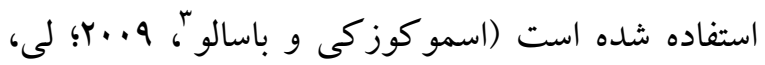

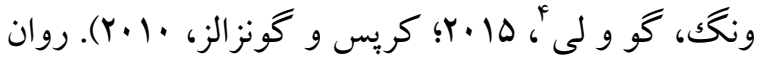
روان نمايشخرى اثر مستقيم بر مشكلات زيربنايى كه

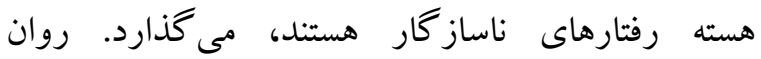
نمايشخرى ممكن است بر سطوح تكانش گرى با واسطه عمل مجدد (نمايش دوباره) در مرحله دوم روان نمايشگرى از طريق گسترده ساختن لحظه براى افرادى كه به نظر مىرسد كذشته را فراموش كردهاند و آينده را نمىيذيرند اثر بحذارد. عمل نمايشى بيشامدها و ويامدها

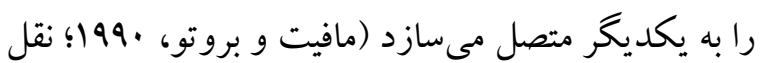

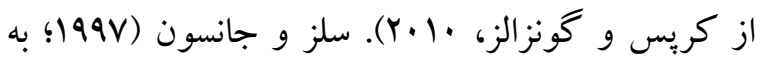
نقل از كريس و كونزالز، · • (Y) نشان دادند كه تكانش كرى از طريق آموزش عمل خيال بافى در فنون بازى درمانى و بازى نقش وجود دارد كاهش مىيابد. بونز -

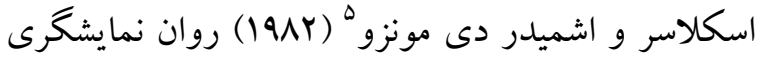
را در درمان افراد با آسيبهاى مغزى از جمله اختلال بيش فعالى / نقص توجه استفاده كردند.

\footnotetext{
1- Moreno ZT, Blomkuist LD, Rutzel

2 - Blatner

3. Smokowski \& Bacallao

4. Li, Wang, Guo \& Li

5 - Bunz-Schlosser \& Schmieder de Munoz
} 
درجهبندى مشكلات رفتارى كانرز (فرم والدين) تشخيص اختلال بيش فعالى / نقص توجه، مورد تأييد قرار

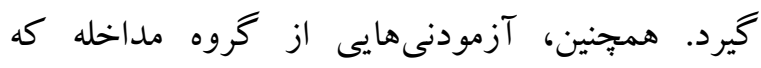
نمى توانستند طبق مقررات برنامه در حداقل 1 جلسه از جلسات روان نمايشخرى شر كت كنند و آزمودنىهايى از كروه كنترل و آزمايش كه امكان تكميل برسشنامهها را رال در مراحل بس آزمون و بيگيرى نداشتند از بززوهش كنار كذاشته شدند. براى تجزيه وتحليل دادهها از آزمون تحليل كواريانس يكك طرفه و براى بررسى نرمال بودن دادهها از آزمون كولمو گروف - اسميرنوف و آزمون شاييرو- ويلك و و براى بررسى بيشفرض تساوى كواريانسها بين متغيرهاى وابسته از آزمون لون با بإن

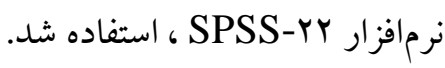

ساعت با فاصله زمانى دو بار در هفته، تحت مداخلهى

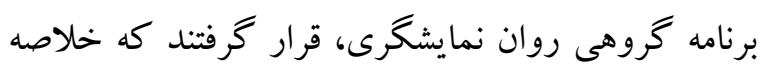
جلسات در جدول ا ارائه شده است. اين در حالى بود كه افراد گرووه كنترل، هيج مداخلهاى دريافت نكردند. در

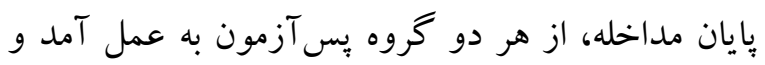

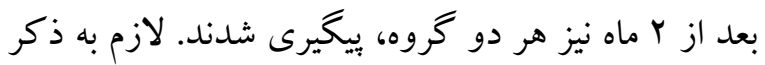
است كه در اين بزّوهش باسخخويى به برسشنامها بدون

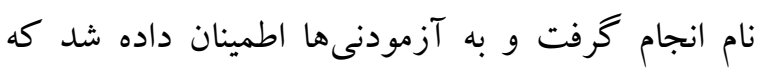
دادهاى به دست آمده از هر نفر، به صورت محرمانه خواهد ماند. همجينين به آزمودنىها كوشزد شد كه آده شركت در بثزوهش كاملاً اختيارى بوده و حق ترك لك يثزوهش را دارند. معيار ورود آزمودنىها به مطالعه به اين صورت بود: آزمودنى و والدين او آمادكى خود را جهت وروديت شركت در يثزوشش اعلام كرده باشند؛ بر اساس مقياس

\section{جدول ا يروتكل روش درمان روان نمايشكرى مورد استفاده در يخوهش حاضر}

\section{جلسه}

\begin{tabular}{|c|c|}
\hline 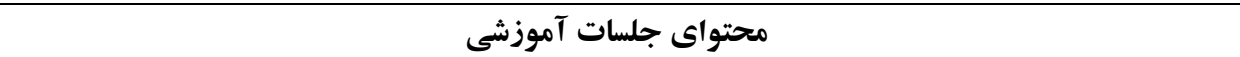 & جلسه \\
\hline 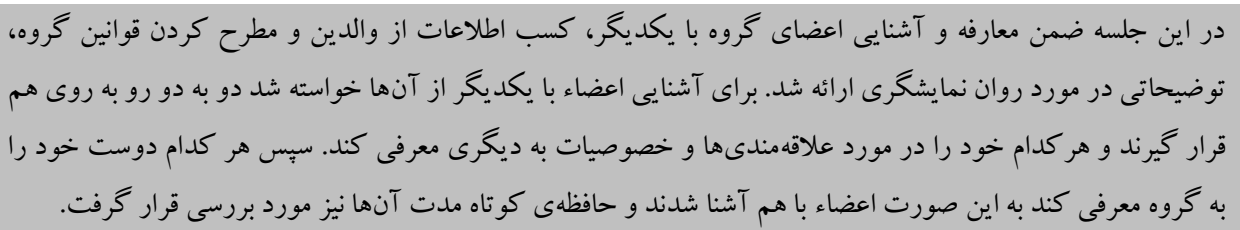 & 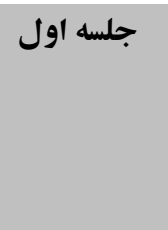 \\
\hline 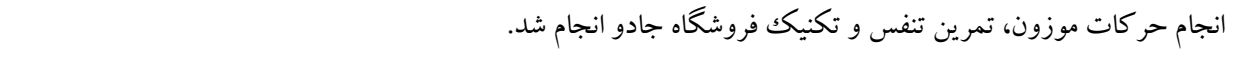 & 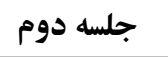 \\
\hline 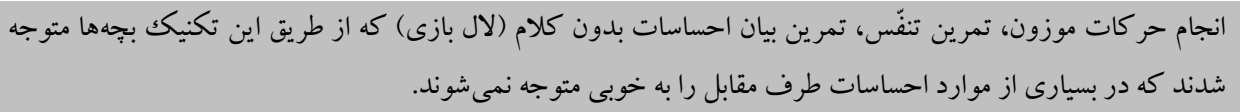 & 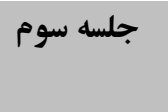 \\
\hline تمرين تنفّس، انجام تمرين آواز خواندن براى يخشكنى، تمرين بيان احساسات بدون كلام، تكنيك جعبهى راز و تكنيك & جلسه جهارم \\
\hline انجام تمر ينات بدنى و انجام تكنيك تصوير سازى ذهنى. & جلسه ينجم \\
\hline در اين جلسه پِ از انجام حر كات ورزشى و تمرين تنفس مجدداً تكنيكك جعبهى راز انجام شد. & 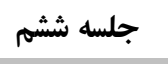 \\
\hline تمرين تنفس، بازىهاى حافظه و بازى نقش. & جلسه هفتم \\
\hline 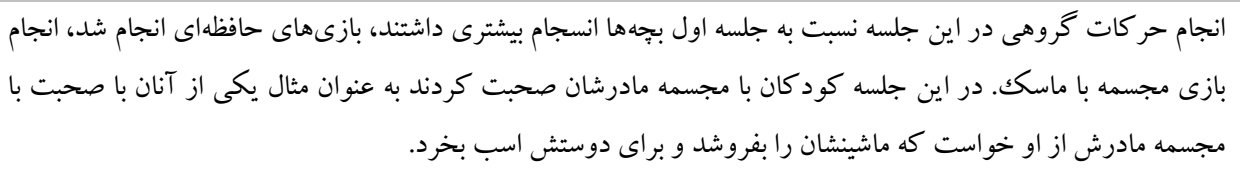 & جلسه هشتم \\
\hline 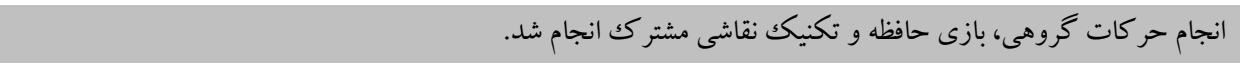 & جلسه نهم \\
\hline مرور مفاهيم آموخته شده، نكات بيشنهادى و آماده كردن اعضا براى اختتاميه، شناسايى موانع موجود در به كار گيرى & 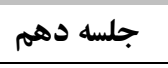 \\
\hline
\end{tabular}


ضرايب همسانى درونى به روش آلفاى كرونباخ V9/ • به دست آمد. مقياس درجهبندى مشكلات رفتارى كانوز (فرم والدينCPRS

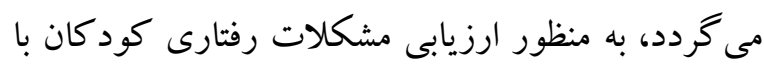
كسترهى سنى ץ تا IV سال تدوين شده است. مشكلات رفتارى كه اين يرسشنامه مورد ارزيابى قرار مىدهد شامل

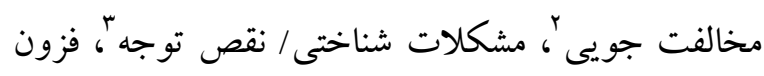

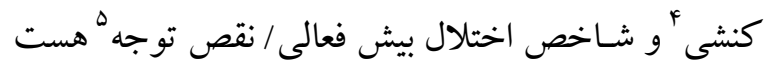
هست كه در F زير مقياس تحت همين عناوين در سؤال كنجانده شده است. هر يكك از سؤالات توسط والدين از · تا س نمره كذارى و نمرههاى خام آزمودنىها از مجموع نمرات به دست آمده براى هر زير مقياس محاسبه مى شود و سبِ بـر اسـاس سـن و جـنس وى به نمرات معيار t تبديل مىشود. نقطه برش براى زير

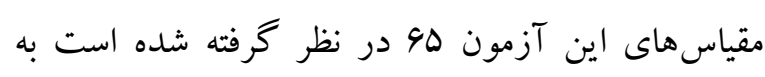
طورى كه نمرهى معيار مساوى يا بيشتر از 9ه، به معنى وجود مسشكلات قابل توجه بالينى در آن زيرمقياس است.

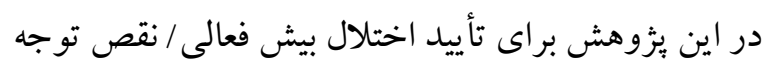
از زير مقياس شاخص اختلال بيش فعالى/ نقص توجه استفاده شد. ضرايب بيايايى درونى زيرمقياسهاى اين آين

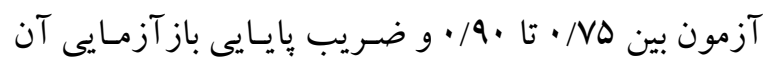

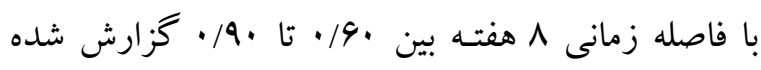
است (به نقل از زركرى نزاد و يكه يزدان دوست، ومشا|). در يزوهش حاضر ضرايب همسانى درونى به روش آلفاى

2. Oppositionality

${ }^{3}$ - Cognitive problems/inattention

4- Hyperactivity

5 - ADHD index
ابز ار آزمون قضاوت اخلاقي: اين آزمون كه براى ارزيابى قضاوت اخلاقى كود كان دوره ابتدايى تدوين شده است، به وسيله سينها و ورما' (199V|-19VI) ساخته شد و در سال 1991 نيز مورد تجديد نظر قرار گرفت و توسط

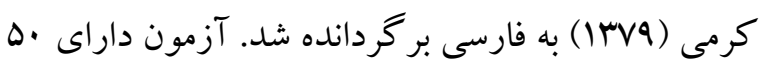
سؤال جندگزينهاى است و آزمودنى بايد درباره آنها تصميم اخلاقى بـيرد، زمينه كار اخلاقى را در برد

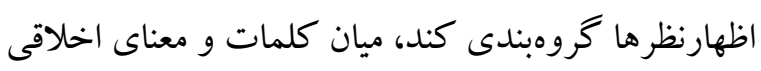
رابطه برقرار نمايد، در برابر مشكلات اخلاقى استدلال

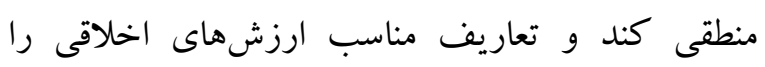
انتخاب نمايد. سؤالات اين آزمون به شش كروه تقسيم شده است كه در آن براى هر سؤال فقط يك ياسخ درست وجود دارد. براى هر ياسخ درست، يك نمره و

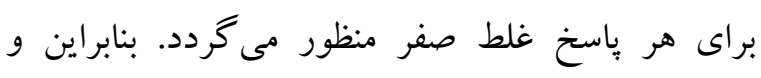
حداقل نمره صفر و حداكثر نمره •ها است. نمره كل، شاخص قضاوت اخلاقى آزمودنى خواهد بود. راهنماهايى كه براى اجراى اين آزمون تهيه شده است،

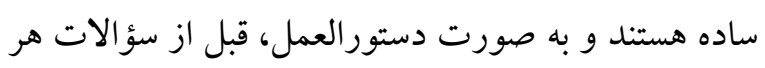
بخش ارائه شدهاند. مدت زمان ياسخكويى كودكان به

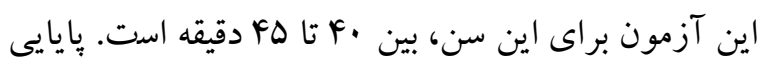

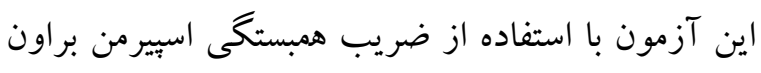
س9/• به دست آمده است (سينها و ورما، 991 (19) ترجمة

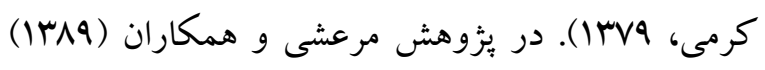

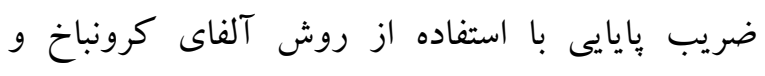
تنصيف 191. و 194/ به دست آمد. در بزوهش حاضر

\footnotetext{
1- Sinha \& Verma
} 


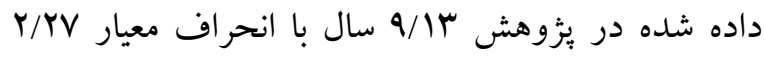
بود كه در آن كمترين سن V سال و بيشترين سن ال ال سال

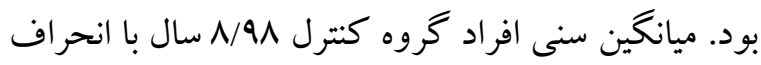

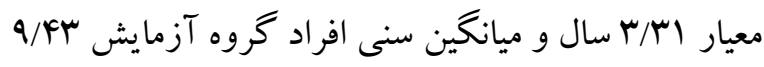

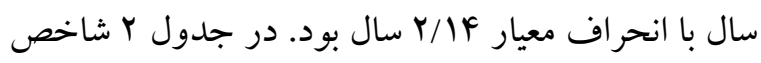
اى توصيفى متغير وابستهى تحول اخلاقى به تفكيكك كروهها و مر احل ارائه شده است.
كرونباخ براى زيرمقياس شـاخص اختلال بيش فعالى/ نقص توجه 199 • به دست آمد.

\section{يافتهها}

بر طبق يافتههاى جمعيت شناختى، تعداد كل آزمودنىها

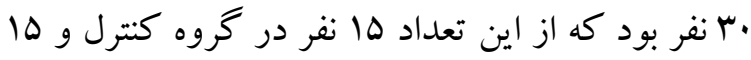
نفر در گروه آزمايش جايگزين شدند؛ كه از اين تعداد در گروه كنترل 9 يسر و 4دختر و در گروه آزمايش نيز

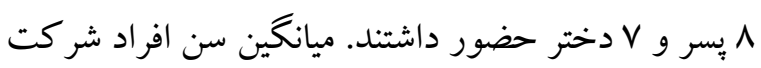

جدول ب ميانكين و انحر اف استاندارد كروه كنترل و آزمايش در نمرات تحول اخلاقى در مراحل مختلف ئل

\begin{tabular}{|c|c|c|c|c|c|c|c|}
\hline \multicolumn{2}{|c|}{ ييغيرى } & \multicolumn{2}{|c|}{ پِ آزمون } & \multicolumn{2}{|c|}{ ييش آزمون } & \multirow[b]{2}{*}{ كروه } & \multirow[b]{2}{*}{ متغير } \\
\hline انحراف اندارد & ميانكين & انتحر اف اندارد & ميانكين & استحراف اندارد & ميانكين & & \\
\hline$r / I V$ & $19 / . \cdot$ & $r / \cdot 1$ & $M / r$. &.$/ 99$ & $1 / N / N$ & كنترل & \multirow{2}{*}{ تحول اخلاقى } \\
\hline $1 / V 9$ & $\mathrm{rV} / \mathrm{WV}$ & $1 / N r$ & YN/AV & $1 / 41$ & IV/AV & آزمايش & \\
\hline
\end{tabular}

برابر با (YV/VV I I/V9) است. همان گونه كه ملاحظه مى گردد ميانخين نمرات تحول اخلاقى آزمودنىهاى كروه آزمايش در مراحل بس بـ آزمون و بيخيرى افزايش محسوسى داشته است. در اين ئزوهش براى بررسى يشيشفرض نرمال بودن توزيع نمرات از آزمون شاييرو -

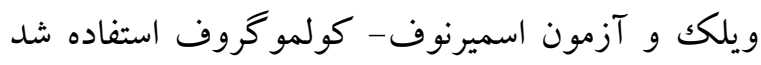
كه در جدول س ارائه شده است.
مطابق با يافتهاى جدول r ميانگين و انحراف استاندارد نمرات تحول اخلاقى در مرحلهى بيش آزمون در گروه باته

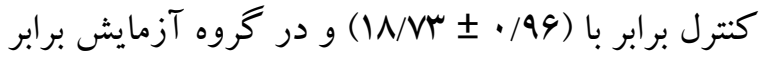

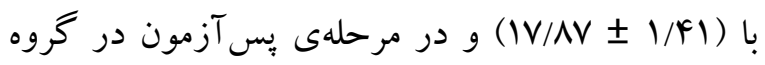

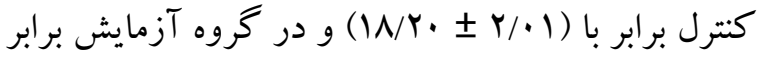
با (YN/AV

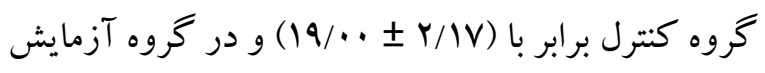

\begin{tabular}{|c|c|c|c|c|c|}
\hline سميرنوف- & كو كو & إييرو- ويلكك & آزمون & \multirow[t]{2}{*}{ تروه } & \multirow[t]{2}{*}{ متغير } \\
\hline سطح معنادارى & Tاره & سطح معنادارى & Tاره & & \\
\hline$\cdot / \wedge \wedge$ &.$/ .94$ & $\cdot / Y \wedge 9$ &.$/ 910$ & كنترل & \multirow{2}{*}{ تحول اخلاقى } \\
\hline$\cdot / r \mid F$ & / IAY & . & - var & آزمايش & \\
\hline
\end{tabular}


كرفته مىشود كه توزيع نمرات نرمال هستند. براى بررسى

ييش فرض همكنى واريانسها بين متغيرهاى وابسته از

آزمون لون استفاده شد كه در جدول ع ارائه شده است.
طبق يافته هاى ارائه شده در جدول r سطح معنادارى آزمونهاى شاييرو-ويلكك و اسميرنوف-كولموكروف در مورد متغير تحليل شده معنادار نبود؛ بنابراين نتيجه

\begin{tabular}{|c|c|c|c|c|c|}
\hline سطح معنادارى & آزادى درجه & آزادى درجه & $\mathbf{F}$ & مرحله & اثرات درون \\
\hline$\cdot /$ TOV & $\Delta r$ & 1 & T/RIT & מֶ آزمون & \multirow[t]{2}{*}{ تحول اخلاقى } \\
\hline.$/ 491$ & $\Delta r$ & 1 & 1/TOF & يبيخيرى & \\
\hline
\end{tabular}

بررسى فقدان تعامل بين كروهها و نمرات بيش آزمون، با طبق يافتهاى ارائه شده در جدول F آزمون لون در مورد استفاده از محاسبه F تعامل بين متغير همبراش و مستقل متغير تحليل شده معنادار نبود ؛ لذا نتيجه گرفته مىشود انجام شد كه در جدول ها ارائه شده است. كه بيش فرض همخنى واريانسها رعايت شده است. براى بررسى بيش فرض همخنى شيب رگرسيون به منظور

\begin{tabular}{|c|c|c|c|c|c|}
\hline معنادارى سطح & $\mathbf{F}$ & مجذيانكين & آزادى درجه & منبع & متغير \\
\hline$\cdot / 119$ & Y/FAV & $r Y / \Lambda \cdot \Delta$ & 1 & تعامل گروه و يِيش آزمون & تحلاقى \\
\hline
\end{tabular}

طبق يافتهاى ارائه شده در جدول ه و با توجه به عدم مقايسهى دو گروه كنترل و آزمايش در متغير تحول

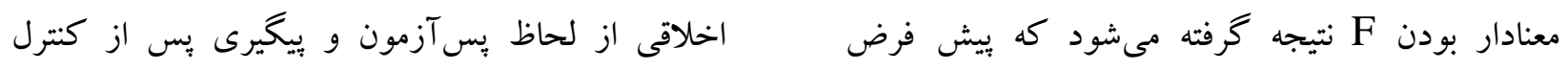
همخنى شيب رگرسيون رعايت شده است. جدول 9 نيز بيش آزمون است. مربوط به آزمون تحليل كواريانس (ANCOVA) براى

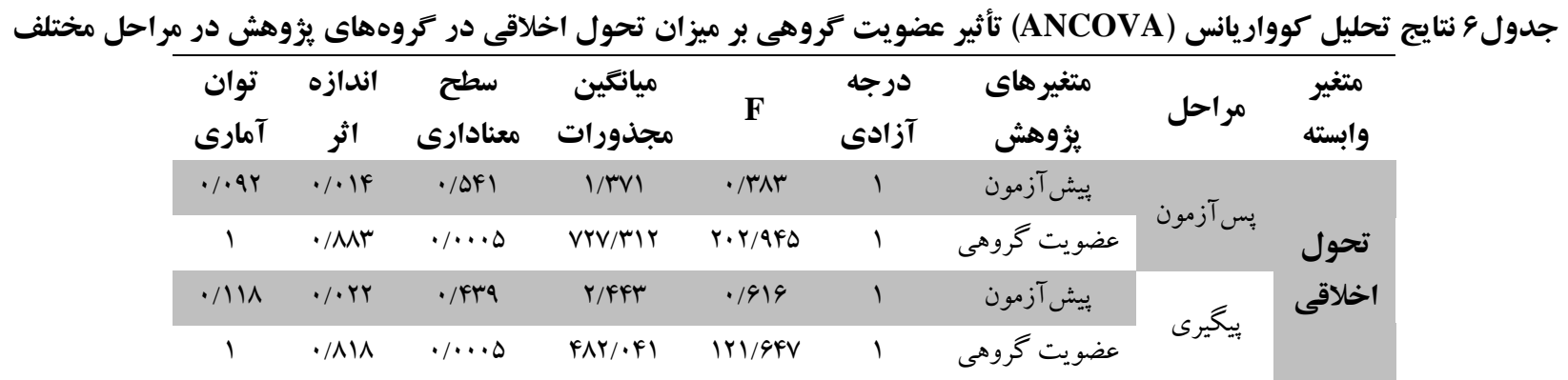


طريق به افراد داده مىشود باعث تقويت و نخهدارى

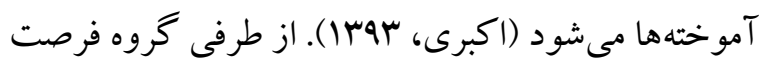
بازخورد دادن به فرد را ايجاد مى كند و فرد در گروه امكان بودن و تجربه اتفاقات كذشته، آينده و فرور فراى نامعلوم را كه در دسترس زمانى و مكانى او نيستند، دارد؛ بنابر اين از طريق اين تجربه به يالايش هيجانى و رسيدن به شناخت در مورد اتفاقات دست مىيابد. احساس بى كفايتى اجتماعى افراد مبتلا به بيش فعالى/ نقص توجه كه منجر به احساس خشم نسبت به دنيا در اين افراد

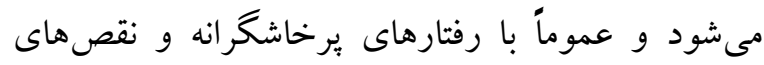
شناختى، رفتارى و هيجانى همر اه است منجر به مورد طرد واقع شدن مى گردد و اين طرد همسالان منجر به از كشته شدن مسائل رفتارى، عاطفى براى آنها مى شود، تعاملات اجتماعى منفى باعث مىشود تا اين افراد نتوانند تجارب عاطفى خود را درك كنند و اين فقدان ظرفيت يردازش هيجانى مرتبط با گسترش ضعف كفايت اجتماعى است

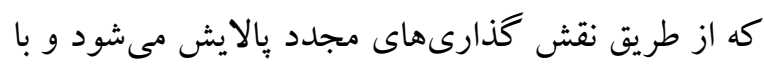
فنون جايخزينى نقشها نقص در درك احساسات ديخران كه منجر به عدم شناخت موقعيت احساسى و رفتارى شده است به سمت بهبود رفته و شاهد رفتارهاى

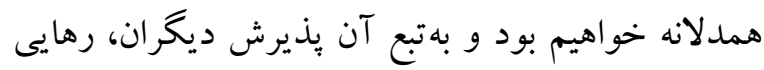
از دست هيجانات منفى و شناخت دنيا به عنوان جايى قابل دوست داشتن و داشته شدن به وجود مى آيد و ظرفيت شناختى فرد گسترش مى يابد و نقصى كه زيربناى قضاوت هاى ناصحيح است مرتفع مىشود (زيدلر و كيفر، (Y..r در تبيين ديخرى از يافتهاى يزٔوهش حاضر مىتوان كفت كه اين كودكان مشكلات قابل توجهى در درئرئر عملكردشان نسبت به ديخران دارند، معمولاً بدون فكر
يافتهاى ارائه شده در جدول 9 نشان مىدهد كه تفاوت مشاهده شده بين ميانگينهاى نمرهى تحول اخلاقى بر بر حسب عضويت گروهى (كروههاى كنترل و آزمايش) در مراحل يس آزمون و بيگيرى معنىدار است (به ترتيب و $\mathrm{F}=|\mathrm{r}| / 94 \mathrm{q}, \mathrm{p}=\cdot / \cdots \Delta, \mathrm{F}=q 4 \Delta / \mathrm{r} \cdot \mathrm{r}$ ه • (

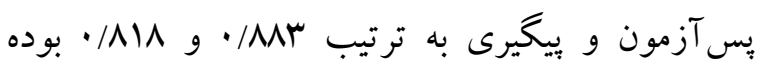
است؛ بنابراين نتيجه گرفته مىشود كه بين ميزان نمرهى تحول اخلاقى بس از اجراى بثزوهش در گروههاى كنترل و آزمايش در مراحل بـ آزمون و بيخيرى، تفاوت

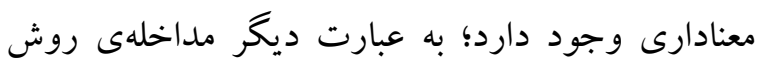
درمانى روان نمايشگرى بر ميزان تحول اخلاقى كود كان مبتلا به اختلال بيش فعالى/ نقص توجه در مراحل پس آزمون گروه آزمايش اثربخش و اين اثربخشى در

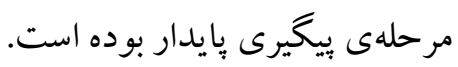

اين يزوهش با هدف بررسى اثربخشى روش درمانى روان

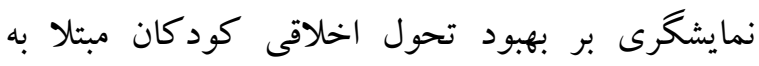
اختلال بيش فعالى/ نقص توجه، انجام گرفت. يافتها نشان داد كه درمان روان نمايشخرى بر تحول اخلاقى كودكان مبتلا به اختلال بيش فعالى/ نقص توجه مؤثر است. اين يافته همسو با يافته هاى، سلز و جانسون (99V)

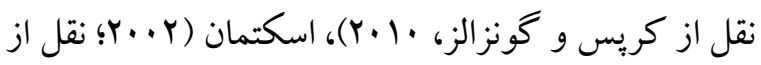

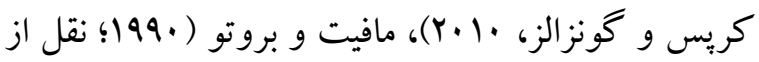

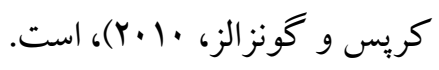
در تبيين اين يافته مىتوان بيان كرد كه روان نمايشگرى از فنون و روشهاى عملى به جاى صحبت كردن استفاده مى كند. اطلاعاتى كه به صورت عملى وارد حافظه مىشوند، يايدارى بيشترى دارند و آموزش هايى كه از اين لي لي 
نامعلوم و آينده كه الان در دسترس زمانى و مكانى نيستند، ادراككهاى مخدوش، نارسايى ارتباطى، پِاسخهاى عاطفى نارسا بررسى و تغيير داده مىشود؛ بنابراين از طريق اين تجربه به بالايش هيجانى و رسيدن به شناخت در مورد اتفاقات دست مى يابد، مىتواند قضاوت كند در لحظه و در موقعيت و شرايط جهه جيزى عادلانه و مناسب است و اين گونه ادراكك اخلاقى و استنتاج تحول مى يابد.

\section{نتيجه كيرى}

به نظر مىرسد در كنار درمانهاى ديخر اختلال بيش فعالى/ نقص توجه، از طريق روش درمانى روان نمايشخرى مى توان بهبود تحول اخلاقى كود كان مبتلا به اختلال بيش فعالى/ نقص توجه را انتظار داشت. بر طبق نتايج حاصل از يزوهش حاضر، به كارگيرى اين نوع

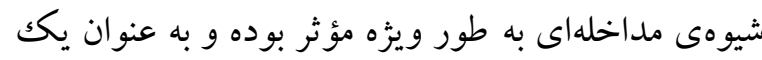
شيوهى مداخلهاى مؤثر و سهل الوصول، بيشنهاد

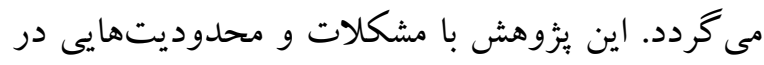

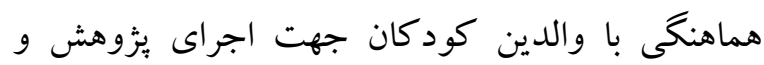
اجراى آزمونها در مراحل مختلف مواجه بود. همجينين با وجود تلاش محقق براى رعايت معيارهاى ورود افراد به يُخوهش، به دليل عدم وجود كنترل كافى بر اين معيارها،

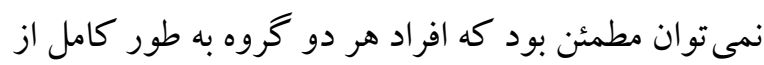
شرايط برابر برخوردار بودند ؛ لذا تعميم يافتهاى تحقيق به كل نمونه هاى خارج از اين دامنه را محدود مى سازد.

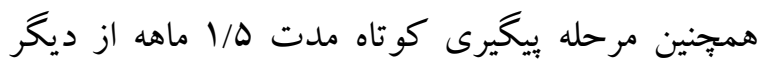
محدوديتهاى بثزوهش است؛ بنابراين بيشنهاد مى گردد در يزوهش هاى آتى ضمن رفع محدوديتهاى ذكر شده يشينهاد مى گردد يزوهش در مقاطع ديخر تحصيلى و سنى انجام شود و با توجه به اين كه گروه تحت درمان يكك جمعيت بالينى بود و براساس مشاهدات اين بيزوهش
كردن عمل كرده و توانايى انتظار كشيدن را ندارند و بدون توجه به بيامدهاى احتمالى دست به كار مىشوند

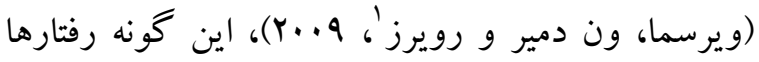
تعامل اجتماعى آنها را مخدوش مىسازد. از نظر ديخران كود كان داراى اختلال بيش فعالى / نقص توجه، افرادى كمدقت، متخاصم، بىادب و برخاشخر جلوه مى كنند. از آنجا كه اخلاق در بطن ارتباط مفهوم نمايانترى مىيابد.

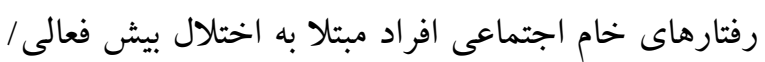
نقص توجه منجر به مورد طرد واقع شدن مى گردد و اين

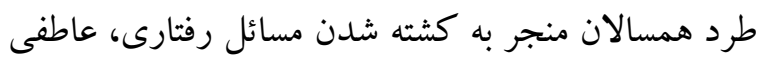
براى آنها مىشود، تعاملات اجتماعى منفى باعث مىشود تا اين افراد نتوانند تجارب عاطفى خود را درك

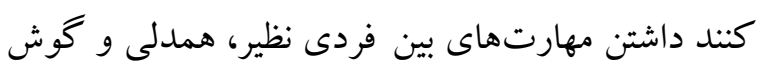
دادن فعال زمينه ارتباط مؤثر را فراهم مى آورد (اسكينر،

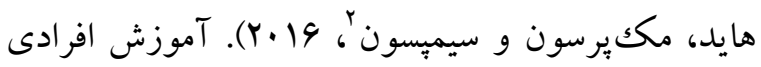
نظير كودكان داراى اختلال بيش فعالى/ نقص توجه، معمولاً با دشوارىهايى به دليل مشكلات نارسايى توجه و

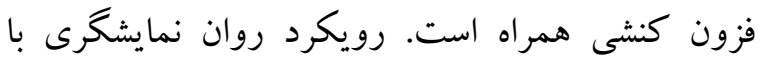
توسعه خزانه نقش و توسعه مهارتهاى رفتارى (مورنو و

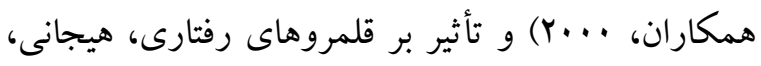
افكار و روابط بين فردى با توجه به آنجه كه درمان

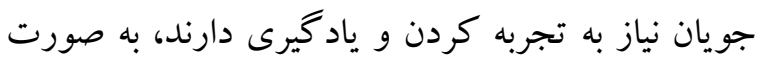
عملى، از طريق تخيل، تكرار موقعيت و فنون ديخر يردازشهاى ناشى از نقص هيجانى را يالايش مىسازد (زيدلر و كيفر، ب...r). ضمن اين كه در شرايط درمان كروهى، با استفاده از فرصت بازخورد دادن به روشى لهى

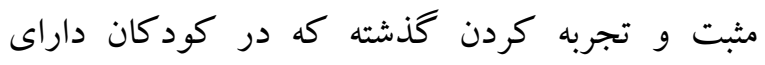
اختلال بيش فعالى/ نقص توجه، دسترسى به فضاى

\footnotetext{
1. Wiersema, van der Meere \& Roeyers

2 - Skinner, Hyde, McPherson \& Simpson
} 
Groman CM, Barzman DH. (2014). The impact of ADHD on morality development. Atten Defic Hyperact Disord, 6(2), 67-71.

Havik J, Halomy A, Lundervorld AJ, Fasmer OB. (2010). Clinical assessment and diagnosed of adult with attention-deficit hyperactivity disorder. ExpertRev, 225, 164-168.

Hoffman ML. (1979). Development of moral thought, feeling, and behavior. American Psychologist, 34(10), 958-966.

Kieling C, Goncalves RR, Tannock R, Castellanos FX. (2008). Neurobiology of attention deficit hyperactivity disorder. Child Adolesc Psychiatr Clin N Am, 17(2), 285-307.

Koenig AL, Cicchetti D, Rogosch FA. (2004). Moral development: The association between maltreatment and young children's prosocial behaviors and moral transgression. Social Development, 13(1), 97-106.

Kreps JJ, Gonzalez T. (2010). The Effects of Maltreatment on Children's Moral Development. MA thesis, in Child Development, Califomia Polytechnic State University, San Luis Obispo.

Li J, Wang D, Guo Z, Li K. (2015). Using psychodrama to relieve social barriers in an autistic child: A case study and literature review. International Journal of Nursing Sciences, 2(4), 402-407.

Marashi M, Safaee-Moghaddam M, Khazami P. (2010). A study of the effects of teaching philosophy by using the community of inquiry method on the moral judgment development in fifth grade primary school students of Ahvaz. Tafakor v Kodak, 102, 1-83. [Persian]

Mones AG, Haswell EC. (1998). Morality as a verb: The process of moral development within the "family culture". Joumal of Social Distress and The Homeless, 7(2), 91-105.

Moreno ZT, Blomkuist LD, Rutzel T. (2000). Psychodrama, Surplus Reality and the Art of Healing. London and Philadelphia: Routledge.

Simoon VC, Zoober P, Batlint S, Meszaros A, Bitter I. (2009). Prevalence and comelates of adult attention-deficit hyperactivity disorder: metaanalysis. BRJ. psychiatry, 194, 2004-2011.

$$
\begin{aligned}
& \text { ييشنهاد مىشود براى دريافت نتيجه بهتر درمان روان }
\end{aligned}
$$

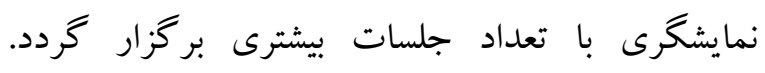

$$
\begin{aligned}
& \text { همجنين بر مبناى مشاهدات بيشنهاد مىشود تعداد افراد } \\
& \text { در خروهها كمتر باشند. } \\
& \text { سياسگزارى }
\end{aligned}
$$

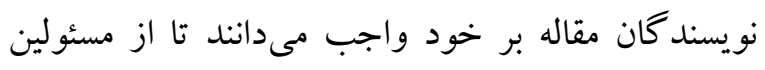

$$
\begin{aligned}
& \text { كلينيكهاى درمانى شيراز و همجنين آزمودنىهاى } \\
& \text { يثزوهش و والدينشان كه در اجراى اين تحقيق ما را } \\
& \text { همر اهى كردند، تشكر و قدردانى نمايند. }
\end{aligned}
$$

\section{References}

Akbari B. (2014). Study effectiveness of psychodrama on executive functions in newly entered nursing students. Journal of Holistic Nursing and Midwifery, 24(1), 1-8. [Persian]

American Psychiatric Association. (2013). Diagnostic and statistical manual of mental disorders $\left(5^{\text {th }}\right.$ ed.). Arlington, VA: Author.

Asherson P. (2005). Clinical assessment and treatment of attention deficit hyperactivity disorder in adults. Expert Rev Neurother, 5(4), 525-39.

Blantner A. (2004). Foundations of Psychodrama: History, Drama, and Practice. Springer Publishing Company.

Broderick PC, Blewitt P. (2006). The life span: Human Development for helping professionals $\left(2^{\text {nd }}\right.$ ed). Upper saddle River, NJ: Prentic Hall.

Bunz-Schlosser G, de Munoz HS. (1982). Psychodrama as a Method of the Clinical Psychotherapy in Rehabilitation of Adults with Brain Damage. In: Pines M., Rafaelsen L. (eds) The Individual and the Group. Springer, Boston, MA.

Faraone SV, Asherson P, Banascheveski T, Bideman J, Boitellar JK, Ramos-Quiroja JA, et al. (2015). Attention-deficit hyperactivity. Nat. Rev. Dis. Prim. L, 6, 15020. 
Sinha D, Verma M. (1998). Moral Judgment Test. Translation by Abolfazl Karami. Tehran: Psychometrics. [Persian]

Skinner KL, Hyde SJ, McPherson K, Simpson MD. (2016). Improving Students' Interpersonal Skills through Experiential Small Group Learning. Joumal of Leaming Design, 9(1), 21-36.

Smokowski PR, Bacallao M. (2009). Entre dos mundus-Between two worlds youth violence prevention-Comparing psychodramatic and support group delivery formats. Small Group Research, 40, 3-27.

Wiersema JR, van der Meere JJ, Roeyers H. (2009). ERP comelates of error monitoring in adult ADHD. Joumal of Neural Transmission, 116(3), 371-379.

Zargari-Nejad G, Yekkeh-Yazdandoost R. (2007). Efficacy of parent's training on problem behaviors in ADHD children. Psychological Studies, 3(2), 29-48. [Persian]

Zeidler DL, Keefer M. (2003). The role of moral reasoning and the status of socioscientific issues in science education: Philosophical, psychological and pedagogical considerations. In D. L. Zeidler (Ed.), The role of moral reasoning and discourse on socioscientific issues in science education (pp. 7-38). The Netherlands: Kluwer Academic Press. 